Abstracta Iranica

Revue bibliographique pour le domaine irano-aryen

Volume 22 | 2001

Comptes rendus des publications de 1999

\title{
« Folklore and anthropology ». Iranian Studies, 31, 3-4, (1998), pp. 325-332.
}

\section{Christian Bromberger}

\section{(2) OpenEdition}

10 Journals

Édition électronique

URL : http://journals.openedition.org/abstractairanica/37338

DOI : 10.4000/abstractairanica.37338

ISSN : 1961-960X

\section{Éditeur :}

CNRS (UMR 7528 Mondes iraniens et indiens), Éditions de l'IFRI

\section{Édition imprimée}

Date de publication : 15 mai 2001

ISSN : 0240-8910

\section{Référence électronique}

Christian Bromberger, « «Folklore and anthropology ». Iranian Studies, 31, 3-4, (1998), pp. 325-332. », Abstracta Iranica [En ligne], Volume 22 | 2001, document 639, mis en ligne le 17 février 2010, consulté le 13 octobre 2020. URL : http://journals.openedition.org/abstractairanica/37338 ; DOI : https:// doi.org/10.4000/abstractairanica.37338

Ce document a été généré automatiquement le 13 octobre 2020.

Tous droits réservés 


\section{« Folklore and anthropology ». Iranian Studies, 31, 3-4, (1998), pp. 325-332.}

\section{Christian Bromberger}

1 Bilan, globalement élogieux, des entrées consacrées au folklore dans l'Encyclopaedia Iranica (lettres A à D). L'A. remarque, à juste titre, qu'une place honorable est donnée à ce domaine d'études dans l'EIr, alors qu'on lui réserve une portion congrue dans des ouvrages de référence similaires, l'Encyclopédie de l'sslam, par exemple. Il regrette l'absence de certaines entrées synthétiques (tel "demonology») et d'une prise en compte suffisante du folklore dans des articles consacrés à la faune, à l'eau, à diverses tribus, etc. Il déplore également que soit très peu pris en considération le «folklore visuel » (''imagerie populaire). Si l'A. est prolixe sur les mérites et les incomplétudes de l'EIr en matière de folklore, il est, en revanche, singulièrement muet sur l'anthropologie. L'une et l'autre disciplines se confondraient-elles pour lui ? Faut-il voir dans cette assimilation ou dans cette négligence une trace de l'héritage de la Volkskunde allemande ou encore du flottement terminologique et conceptuel des éditeurs de l'EIr dans leurs découpages disciplinaires?

\section{INDEX}

Thèmes : 16.0. Généralités 
AUTEURS

CHRISTIAN BROMBERGER

Université d'Aix-en-Provence 